\title{
AMERICAN CULTURAL VARIATIONS ON THE DEMONIC
}

Interest in the occult as a subcultural phenomenon has grown alarmingly in the last decade and continues to proliferate as even the most cursory perusal of metropolitan bookstores will confirm, but the so-called scientific approach is fortunately still limited in appeal. Paperback book sales and cinema more than television have accounted recently though for the general popularity of certain selfstyled works of the imagination, e.g., Ira Levin's Rosemary's Baby (1967), Thomas Tryon's The Other (1971), and William Peter Blatty's The Exorcist (1971). The question that perplexes the analyst of cultural trends in the face of this mass exposure to the return of the demon as persona is whether we are experiencing a genuine recurrence of the figural imagination in an age that has generally accepted its decline if not demise. Nathan Scott has called ours "a world, indeed, which, being independent of any otherworldly plan or scheme of meaning, has ceased to be a figura of anything extrinsic to itself and is sealed off against any transcendental ingress from without" (The Wild Prayer of Longing, p. 25).

The demon as persona is all but absent from American literature until the present as a literary phenomenon to be reckoned with; however, demonic analogues have played a significant part in American letters. There are two strands of American literary variations on the demonic, and both, it seems to me, are at least broadly figural (pace Scott) inasmuch as the principal works employing demonic analogues impart a sense of the mystery of evil that cannot simply be explained as the sum of man's offenses or controlled through merely human efforts. The retrospective variation emphasizes the privatized demon in man's heart and traces a literary line from Hawthorne through Nathanael West to Flannery O'Connor; the proleptic strain imagines the mythical end-time of the last loosing of Satan, yet in terms of the protean social presence of the confidence man from Melville and Twain through West into the present in Ellison, Barth, Pynchon, Heller and Percy. Whereas the strand of the demonic heart seeks the origins of man's present failure in the Edenic covenant with the serpent, the loosing of Satan motif projects the result of man's continuing perversity into a catastrophic future of crisis.

Whatever else one may say about Blatty's adaptation of The Exorcist for the screen and William Friedkin's direction of it, the film's introductory sequence in Northern Iraq establishes a cosmic context for the vulgar Georgetown incident that avoids the novel's almost trite clinical tone and inconclusive ending. There is, however, a regrettable Neo-Puritan implication in both the novel and the film that sex is demonic since practically all of Regan's aberrant activities are portrayed in terms of sexual excesses. The Exorcist's most signifi- 
cant and unpardonable omission though is its failure to portray any evil in the immediate world comparable to what the demon perpetrates in Regan.

The Exorcist and similar contemporary cultural phenomena seem without exception to be guilty of man's recurring, intellectually primitive tendency to abdicate responsibility for his crimes by making the source of evil external to himself. For this reason alone the recurrence of the demonic persona is aesthetically unjustifiable and intellectually reprehensible. And although the literary interiorization of evil does not necessarily entail the demise of the figural, particularly in the loosing of Satan strain, the return of the demonic persona as pure externalization of evil clearly destroys any literal basis for the figural.

-JOHN R. MAY, S.J.

\section{THE NEW RELIGIONS}

One of my students has been interviewing recent converts to various of the "new religions" abroad in our land these days, with surprising results. Surprising to me, at least. Reading through her transcripts, I find it difficult to tell the Buddhists from the Christians. Nor can I easily discern any Buddhist content to this new Buddhism, nor Christian content to this Christianity. A student who has converted to the Nichiren Shoshu (better known in Japan as the Soka Gakkai) reports that he began chanting a little over a year ago, when his girl introduced him to the practice. Part of the appeal of Nichiren Buddhism for him was the absence of all talk of right and wrong. "I knew it didn't have a moral code," he says. "This religion doesn't treat your consciousness as being infantile."

A young woman who has found an intensely devotional relationship to Jesus through a charismatic group called the Way Ministry speaks in a very similar vein. My student asks her, "Is there a moral code in the Way Ministry that says you shouldn't do this or that?" and she responds: "No. There is an emphasis on the fact that a life that is going to be successful has to be committed to something. Christ says he came to give us a more abundant life, not a bunch of rules and regulations. In fact he came to abolish all rules and regulations, and we were set free." She goes on to say, however, that "there is definitely a way that God wants people to live; he wants you to be loving, to be good, to be good to yourself, respect yourself, and to love God more than anything else in the world. If you do that you feel really good, and your prayers are answered." 